\title{
Assessment of heavy metals in soil, paddy straw and SEM analysis of the soil for the impact of wastewater irrigation in Girudhumal sub basin of Tamil Nadu, India
}

\author{
Dhanasekarapandian M. ${ }^{1}$, Chandran S. ${ }^{1}$, Kumar V., ${ }^{2,}$ and Surendran U. ${ }^{3}$ \\ ${ }^{1}$ Department of Civil Engineering, Thiagarajar College of Engineering, Madurai-625015, Tamil Nadu, India \\ ${ }^{2}$ Department of Agricultural Engineering, Agricultural College and Research Institute, Tamil Nadu Agricultural University, Madurai \\ 625104, India \\ ${ }^{3}$ Water Management (Agriculture) Division Centre for Water Resources Development and Management, Kozhikode, Kerala, India - \\ 673571
}

Received: 31/05/2018, Accepted: 19/11/2018, Available online: 21/11/2018

https://doi.org/10.30955/gnj.002784

\begin{abstract}
The objective of the study is to determine accumulation and translocation of heavy metals from soil to paddy straw irrigated with urban sewage wastewater in peri-urban region of Girudhumal sub basin area in Madurai. The soil samples were collected in seven locations irrigated with treated and untreated wastewater and analyzed for physical properties like pH, EC, bulk density, soil type, major ( $\mathrm{N}, \mathrm{P}, \mathrm{K})$ and micro nutrients ( $\mathrm{Fe}$, $\mathrm{Mn}, \mathrm{Cu}, \mathrm{Zn}$ ) and heavy metals $\mathrm{Ni}, \mathrm{Cd}, \mathrm{Pb}$. SEM analysis showed that soil structure is significantly influenced by waste water irrigation. It confirms that the waste water irrigation disturbs soil structure and affecting the plant growth in long run. $\mathrm{Pb}$ content was higher than the prescribed safe limits in $\mathrm{S} 5$ and $\mathrm{S} 6$ location, similarly $\mathrm{Ni}$ also was higher than the safe limit in all the locations. Pollution Load Index values are in the range of 0.08-0.56 for all sites, and it indicated that chance of heavy metal contamination is less. The EF values show moderate enrichment to $\mathrm{Ni}$ and $\mathrm{Zn}$, significant enrichment for $\mathrm{Cd}$ and $\mathrm{Cu}$, extremely high for $\mathrm{Pb}$ and deficiency for $\mathrm{Mn}$. All these results confirmed that there is no immediate risk of heavy metal pollution, however with respect to $\mathrm{Pb}$ and $\mathrm{Ni}$ the plant tissues are showing higher values. The transfer factor for heavy metals from soil to paddy straw is less than 0.5 for $\mathrm{Cd}$ and for others is more than 0.5 indicated greater chances for heavy metal contamination.
\end{abstract}

Keywords: Heavy metals, paddy straw, pollution load index, enrichment factor, translocation factor, SEM.

\section{Introduction}

Sustainable development of agriculture in India is restricted by a major factor of water scarcity, since in India water is scarce due to the increasing growth in population, rapidly growing urbanization, industrialization and economic development. Severe water shortages are developing in many countries and water for agriculture is becoming increasingly scarce, particularly in India (Surendran et al., 2014, 2016, 2017). Access to adequate water for irrigation is a matter of concern in India, to meet demand for irrigation water for agriculture (i.e. more than $80 \%$ of water use is for agriculture), non-conventional resources are used.

Availability and disposal of huge quantity of wastewater, due to the growth of industrial sector in India, is becoming a major problem, which makes the growing economies under pressure to sort it out (Minhas and Samra, 2004; Corcoran et al., 2010). The technologies for treating wastewaters are often costly (Levy et al., 2011), whereas the optimal use of wastewaters in agriculture for irrigation makes this as a low-cost alternative to treatment and helps in preventing uncontrolled dumping of wastewaters into water bodies (Drechel et al., 2010). Nowadays, wherever water is scarce, wastewater is often used for irrigation/agricultural purpose. Review of literature showed that this was put into practice first in Melbourne, Australia, where sewage farms were established in 1897 (Shuval, 1990; WHO, 2006) and later being practiced in many countries such as New Zealand, China, India, Pakistan (Yang et al., 2007; Minhas and Lal, 2010)

Waste water irrigation (diluted or partially treated or raw), has both advantages and disadvantages. The benefits are conserving water and nutrients, reducing the pollution of water bodies, providing nutrients especially micronutrients and organic matter (FAO, 1992; Murtaza et al., 2010; Hanjra et al., 2012) and reliable irrigation resource in water scarce conditions which makes millions of urban and peri-urban farmers to depend on these waste water for their food security and livelihood options (Hoeks et al., 2002; Qadir et al., 2007).

On the other hand, the irrigation practices being primitive, unscientific and more of disposal oriented, these pose 
threat to farmer's/consumer's health and the environment through transmission of diseases from excreta related pathogens and vectors, skin irritants and irreversible accumulation of toxic chemicals like heavy metals, pesticides etc. in soils and groundwater (Yadav et al., 2002; Rattan et al., 2005; Qadir et al., 2007, 2010; Minhas and Lal, 2010; Murtaza et al., 2010).

However, this wastewater based irrigation has a number of limitations, includes the pollution of groundwater, built up of heavy metals, pesticides and other pollutants in the soil and the creation of habitat for harmful microorganisms which pose threat to farmer's/consumer's health and the environment through diseases from pathogens and vectors (Mapanda et al., 2005; Murtaza et al., 2010; Qadir et al., 2010 and Minhas et al., 2015). Several studies confirmed the presence of heavy metals (Mogen Henze et al., 2002; Cao and $\mathrm{Hu}$, 2004; Mapanda et al., 2005; Nan et al., 2002; Huang et al., 2017; Yan et al., 2018) and their potential bioaccumulation, when wastewater is used for irrigation. Papaioannou et al. (2015) proposed a method for accumulation of heavy metals by quantification and prediction of the pollution by way of elemental interactions i.e antagonistic or synergistic. Transfer of these heavy metals, from soil ecosystem to plant, depends on the heavy metal interaction in soil (Kalavrouziotis et al., 2012). Heavy metals are highly toxic for plants; phytotoxicity cause chlorosis, affects plant growth, variation of yields, reduced nutrients uptake and changes metabolism of plants (Broos et al., 2005; Qadir et al., 2000). Wastewater mixed with river water used for crop irrigation for more than a decade, have caused metal accumulation viz $\mathrm{Cd}, \mathrm{Pb}, \mathrm{Ni}, \mathrm{Zn}, \mathrm{Cr}$ and $\mathrm{Co}$ into $31 \%$ of soil surface (Assadian et al., 1999). Transfer function (TF) calculation will suggest the interactions between these heavy metals in the soil and how they are getting transferred from soil to plants (Kalavrouziotis and Koukoulakis, 2009; Kalavrouziotis et al., 2012). These heavy metals enter the food chain and can result in a number of disorders to human health when concentrations exceed the safe limits (Martin and Griswold, 2009). The heavy metal toxicity affects the human populations by way of neurological disorders, central nervous system destruction, cancers of various body organs etc. to name a few (ATSDR, 1999). The authors have conducted studies for wastewater irrigated soil for heavy metal contamination. The alleviation policies to reduce heavy metal exposure through food are usually overlooked (Sharma et al., 2014).

By keeping the above factors, it is most important to monitor soil health where wastewater irrigation being carried out in order to prevent the entry of heavy metals into food chain. Girudhumal river total length is $84 \mathrm{~km}$, which flows in urban and peri urban stretch of Madurai for the first $24 \mathrm{~km}$, carries urban sewage, solid waste, small scale industries wastes water ends with nearby peri urban irrigation tanks. Due to shortage of water for agriculture, this water is directly used for irrigation without prior treatment. Paddy crop (Oryza Sativa) is mainly cultivated on commercial scale using this untreated waste water for the past three decades around 800 acres during rainy seasons. There is no information on heavy metals in soil and paddy crop in these areas. This study is aimed to assess the pollution indices and translocation of heavy metals from soil to paddy straw and assessing the physical structure of the soil using Scanning Electron Microscope (SEM) analysis on the impacts of long term waste water irrigation.

\section{Materials and methods}

\subsection{Study area}

The study area selected was in the urban reach of Girudhumal river (with a length of $28 \mathrm{~km}$ ) of Madurai city of Tamil Nadu, Southern part of India and situated at $9^{\circ} 25^{\prime}$ $\mathrm{N}$ to $78^{\circ} 25^{\prime} \mathrm{E}$ as shown in Figure 1 . It receives all the domestic sewage, solid waste, rice mill, bleaching and small-scale industries wastes in and around Madurai region. Moreover, the city drainage of Avaniyapuram Channel, Chinthamani Channel, Anuppanadi Channel, Panaiyur Channel and Sotathatti channel are joining into river. This river water is retained in large and small tanks and diverted to irrigation canals to be used by farmers for agricultural purposes and nearly 800 acres land get benefit for the past three decades. The predominant soil texture is clayey, loam and clay loam soils. This soil layers are in general fertile and suitable for growing many crops and paddy is the predominant crop in that area for both Rabi and Kharif period. The other crops cultivated are groundnut, banana, vegetables viz., Chilly and Greens. Urban and Peri urban reach of this area receives $806 \mathrm{~mm}$ of average annual rainfall, temperature varies from $15^{\circ}$ to $41^{\circ} \mathrm{C}$ and relative humidity varies from 45 to $85 \%$ and high in NE monsoon (Water Year, 2007).

\subsection{Soil sampling locations}

Seven sites were selected as shown in Figure 1 for collection of soil and paddy straw samples namely Thuvariman $\left(9.9585^{\circ} \mathrm{N}, 78.0524^{\circ} \mathrm{E}\right)$ (S1) as controlled site irrigation with bore well water remaining six places are irrigated with treated and untreated wastewater namely Avaniyapuram $\left(9.8771^{\circ} \mathrm{N}, 78.1137^{\circ} \mathrm{E}\right)$ (S2), Kaluvankulam $\left(9.9252^{\circ} \mathrm{N}, 78.119^{\circ} \mathrm{E}\right)$ (S3), Chinthamani $\left(9.892^{\circ} \mathrm{N}, \quad 78.1413^{\circ} \mathrm{E}\right)$ (S4), Samanatham $\left(9.866^{\circ} \mathrm{N}\right.$, $\left.78.147^{\circ} \mathrm{E}\right)(\mathrm{S} 5)$, Sottathatti $\left(9.8616^{\circ} \mathrm{N}, 78.1671^{\circ} \mathrm{E}\right)(\mathrm{S} 6)$ and Virathanoor $\left(9.8142^{\circ} \mathrm{N}, 78.1771^{\circ} \mathrm{E}\right)$ (S7). Sampling in all the stations were taken in the year of October, 2015.

\subsection{Soil and paddy straw sample collection}

Soil and paddy straw samples were collected in October 2015 at the time of farmers harvested the crops. Straw from 10-20 paddy clumps were collected randomly from seven selected sites with same physiological age and identical size. All the samples were oven dried at $65^{\circ}$ for 24 hours and samples are dried, pulverized in wiley mill and stored in polythene bags for analysis. In order to analyze the influence of soil properties on agronomic performance, and to assess the impact of waste water irrigation, representative soil samples were taken 
from each field at post-harvest stage. Samples were taken from the cultivated soil layer (upper $20 \mathrm{~cm}$ ), using a single auger and combining 12 samples evenly distributed over the field to one composite sample. The samples were air dried, crushed, and gravel and other particles of more than $2 \mathrm{~mm}$ were removed with a sieve. The samples were analysed in the soil laboratory, for the parameters listed below.

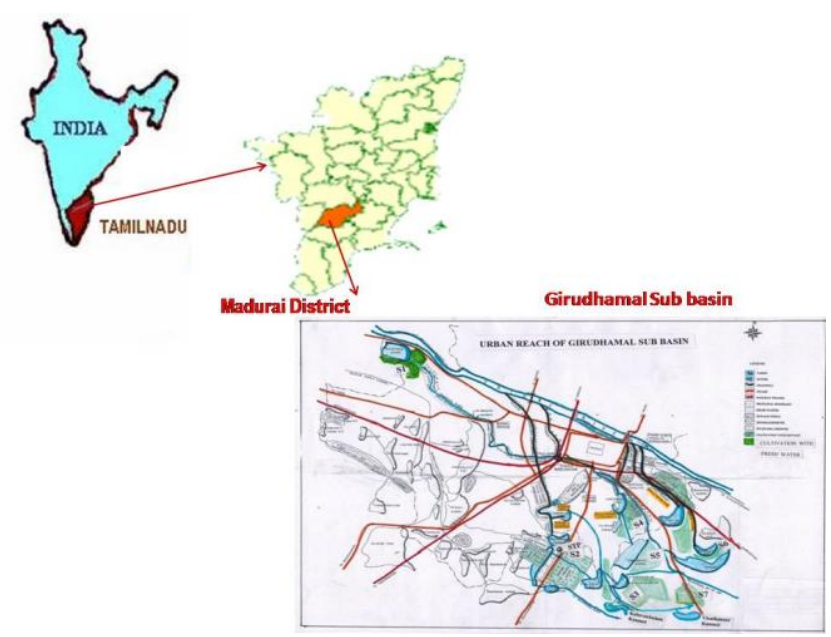

Figure 1. Study area

\subsection{Analytical procedures adopted}

The $\mathrm{pH}$ of soil was determined using Elico $\mathrm{pH}$ meter and EC was determined using a conductivity bridge (Jackson, 1973). The bulk density was determined by gravimetrically by Keen-Raczkowski brass cup. The Organic Carbon content of soil was estimated by chromic acid wet digestion method (Walkely and Black, 1934). The available Nitrogen by Macrojeldahl method (Piper, 1966), Phosphorus by Vandomolybdate method and Potassium by Flame photometric method in $\mathrm{HCl}$ extract (Stanford and English, 1949). For heavy metal extraction, $1 \mathrm{~g}$ of dried sample of soil or paddy straw was digested in $15 \mathrm{ml}$ of $\mathrm{HNO}_{3}, \mathrm{H}_{2} \mathrm{SO}_{4}$ and $\mathrm{HClO}_{4}$ mixture $(5: 1: 1)$ at $80^{\circ} \mathrm{C}$ until a transparent solution was obtained (Allen et al., 1986). These transparent solutions were then filtered through Whatman number 42 filter paper and diluted to $50 \mathrm{ml}$ with distilled water. The concentration of heavy metals $\mathrm{Ni}, \mathrm{Cd}, \mathrm{Pb}, \mathrm{Cu}, \mathrm{Fe}, \mathrm{Zn}$ of soil and paddy straw samples were analyzed by atomic absorption spectroscopy (AAS, AA250-VARIAN). The AAS value of blank (without sample) of each metal was deducted from the sample value for final calculations (Singh et al., 2010). The characteristics of soil structure analyzed by Phillips X2-30 Scanning Electronic Microscope (SEM) with a $3.5 \mathrm{~nm}$ of resolution. Glass was properly cleaned and blank determination was used to correct the reading of instruments. The results were found to be + or $-2 \%$ of the certified values.

\subsection{Pollution load index (PLI)}

To calculate the soil pollution severity, Pollution Load Index is used (Tomlison et al., 1980; Harikumar et al., 2009) and the equation for PLI was derived based on the concentration factors of each metals. The PLI of the place is calculated by obtaining the n-root from the nCFs that were obtained for all the metals which is given in equation 1 as follows,

$\mathrm{CF}=\mathrm{C}$ metal $/ \mathrm{C}$ background value,

$\mathrm{PLI}=\mathrm{n}<\sqrt{\left(\mathrm{CF}_{1} \times \mathrm{CF}_{2} \times \mathrm{CF}_{3} \ldots \mathrm{CF}_{\mathrm{n}}\right)}$

Where $\mathrm{CF}=$ Contamination Factor, $\mathrm{n}=$ no. of metals

$\mathrm{C}$ metal $=$ Metal Concentration in Polluted Sediments.

$\mathrm{C}$ background Value $=$ Background value of the metal

The $\mathrm{PLI}$ value $>1$ is polluted, whereas $<1$ indicates no pollution.

Turekian and Wedepohl (1961), considered the World Average concentration of $\mathrm{Cu}(45 \mu \mathrm{g} / \mathrm{g}), \mathrm{Ni}(68 \mu \mathrm{g} / \mathrm{g}), \mathrm{Mn}$ $(900 \mu \mathrm{g} / \mathrm{g}), \mathrm{Pb}(20 \mu \mathrm{g} / \mathrm{g})$ and $\mathrm{Cd}(0.3 \mu \mathrm{g} / \mathrm{g})$ reported as the background value.

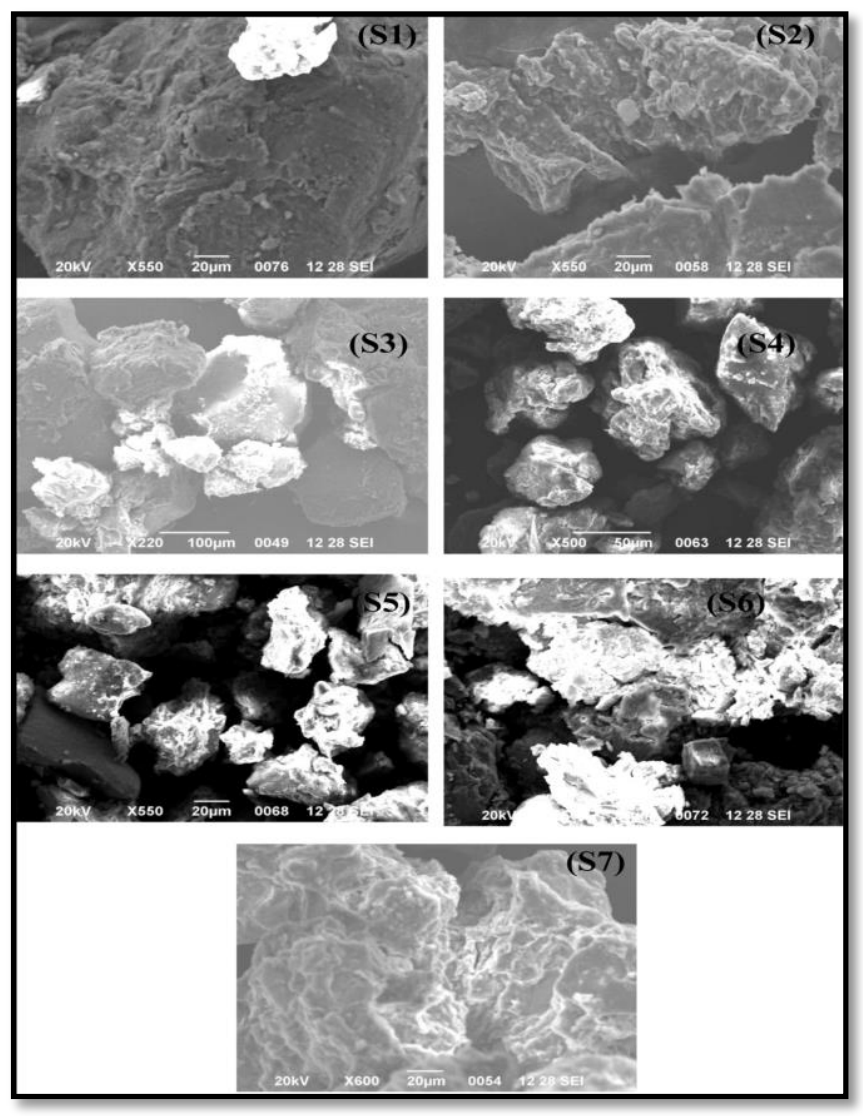

Figure 2. SEM Morphological image for different sites in the study area

\subsection{Enrichment factor}

The Enrichment Factor (EF) was calculated to drive the degree of soil contamination and heavy metal accumulation soil and plants growing on contaminated site with respect to soil and plants growing on uncontaminated soil (Kisku, Barman and Bhargava, 2000). When $E F<2$ it may be deficiency to mineral enrichment, $E F$ $=2-5$ it is moderate enrichment, $\mathrm{EF}=5-20$ it is significant enrichment, $E F=20-40$ it is very high enrichment, EF>40 it is extremely high enrichment. 
Table 1. Physico-chemical properties of soil irrigated with treated, untreated and bore water irrigation

\begin{tabular}{|c|c|c|c|c|c|c|c|c|c|c|c|c|c|c|}
\hline \multirow{2}{*}{$\begin{array}{l}\text { Sampling } \\
\text { sites }\end{array}$} & \multirow[b]{2}{*}{$\mathrm{pH}$} & \multirow[b]{2}{*}{$\mathrm{EC}(\mathrm{dS} / \mathrm{cm})$} & \multirow{2}{*}{$\begin{array}{c}\text { Bulk } \\
\text { density } \\
\text { (g/m3) }\end{array}$} & \multirow{2}{*}{$\begin{array}{c}\text { Organic } \\
\text { carbon } \\
(\%)\end{array}$} & \multirow{2}{*}{$\begin{array}{c}\text { Soil } \\
\text { texture }\end{array}$} & \multicolumn{3}{|c|}{ Available (kg/ha) } & \multirow[b]{2}{*}{$\mathrm{Fe}(\mathrm{mg} / \mathrm{kg})$} & \multirow{2}{*}{$\begin{array}{c}\mathrm{Mn} \\
(\mathrm{mg} / \mathrm{kg})\end{array}$} & \multirow[b]{2}{*}{$\mathrm{Zn}(\mathrm{mg} / \mathrm{kg})$} & \multirow[b]{2}{*}{$\mathrm{Cu}(\mathrm{mg} / \mathrm{kg})$} & \multirow{2}{*}{$\begin{array}{c}\text { Available } \\
\text { Sulphur } \\
\text { (kg/ha) }\end{array}$} & \multirow[b]{2}{*}{ Irrigation } \\
\hline & & & & & & $\mathbf{N}$ & $\mathbf{P}$ & K & & & & & & \\
\hline S1 & 7.93 & 270 & 1.25 & 0.42 & Loam & 218 & 32 & 779 & 2.41 & 8.41 & 1.51 & 2.09 & 6.9 & $\begin{array}{c}\text { Bore Well } \\
\text { Water }\end{array}$ \\
\hline S2 & 8.72 & 666 & 1.25 & 0.56 & Clay Loam & 104 & 37 & 503 & 3.47 & 15.46 & 1.28 & 3.86 & 32.9 & $\begin{array}{c}\text { Untreated } \\
\text { Sewage }\end{array}$ \\
\hline S3 & 8.80 & 290 & 1.26 & 0.8 & Sandy & 230 & 150 & 229 & 35.51 & 16.57 & 1.38 & 1.5 & 11.4 & $\begin{array}{c}\text { Treated anc } \\
\text { Untreated } \\
\text { Sewage }\end{array}$ \\
\hline S4 & 8.11 & 770 & 1.33 & 0.78 & Clay Loam & 210 & 38 & 872 & 11.17 & 10.58 & 7.37 & 48.31 & 4.3 & $\begin{array}{c}\text { Untreated } \\
\text { Sewage }\end{array}$ \\
\hline S5 & 8.55 & 660 & 1.25 & 0.82 & Clay & 162 & 22 & 948 & 12.19 & 15.14 & 2.65 & 11.24 & 3.3 & $\begin{array}{c}\text { Untreated } \\
\text { Sewage }\end{array}$ \\
\hline S6 & 8.11 & 770 & 1.33 & 0.75 & Clay & 434 & 60 & 903 & 27.95 & 15.6 & 19.14 & 61.64 & 14.6 & $\begin{array}{c}\text { Untreated } \\
\text { Sewage }\end{array}$ \\
\hline S7 & 8.37 & 1.36 & 1.11 & 0.82 & Clay & 112 & 120 & 631 & 2.4 & 0.22 & 0.42 & 1.61 & 12.5 & $\begin{array}{c}\text { Treated anc } \\
\text { Untreated } \\
\text { Sewage }\end{array}$ \\
\hline
\end{tabular}

Table 2. Heavy metal concentration in soil

\begin{tabular}{|c|c|c|c|c|c|c|c|}
\hline Places & Sites & $\mathbf{N i}$ & $C d$ & $\mathrm{~Pb}$ & $\mathrm{Zn}$ & $\mathrm{Cu}$ & $M n$ \\
\hline Thuvariman & S1 & 1.77 & 0.12 & 0.05 & 1.51 & 2.09 & 8.41 \\
\hline Avaniyapuram & $\mathrm{S} 2$ & 5.26 & 0.1 & 1.15 & 1.28 & 3.86 & 15.46 \\
\hline Kaluvankulam & S3 & 3.38 & 0.31 & 1.25 & 1.38 & 1.5 & 16.57 \\
\hline Chinthamani & S4 & 5.36 & 0.82 & 0.16 & 7.37 & 48.31 & 10.58 \\
\hline Samanatham & S5 & 3.83 & 1.86 & 3.99 & 2.65 & 11.24 & 15.14 \\
\hline Sottathatti & S6 & 11.47 & 0.81 & 8.89 & 19.14 & 61.64 & 15.6 \\
\hline Virathanoor & S7 & 4.32 & 0.85 & 0.52 & 0.92 & 4.03 & 17.32 \\
\hline Mean & & 5.06 & 0.70 & 2.29 & 4.89 & 18.95 & 14.15 \\
\hline Median & & 4.32 & 0.81 & 1.15 & 1.51 & 4.03 & 15.46 \\
\hline SD & & 3.08 & 0.61 & 3.20 & 6.67 & 25.11 & 3.33 \\
\hline Indian Standard (Awasthi, 2000) & & $75-150$ & $3-6$ & $250-500$ & $300-600$ & $137-270$ & - \\
\hline WHO/EU standards (EU, 2002) & & 75 & 3.0 & 300 & 300 & 140 & - \\
\hline
\end{tabular}




\subsection{Translocation factor}

Translocation factor from soil to crop or mobilization ratio (Barman et al., 2000; Gupta et al., 2008 and Cui et al., 2004) was calculated to examine the relative

Table 3. Heavy metal concentration in paddy straw

\begin{tabular}{cccccccc}
\hline Places & Sites & $\mathbf{N i}$ & $\mathbf{C d}$ & $\mathbf{P b}$ & $\mathbf{Z n}$ & $\mathbf{C u}$ & $\mathbf{M n}$ \\
\hline Thuvariman & $\mathrm{S} 1$ & 1.52 & 0.01 & 0.04 & 192 & 54 & 35 \\
\hline Avaniyapuram & $\mathrm{S} 2$ & 4.30 & 0.08 & 1.02 & 110 & 45 & 67 \\
\hline Kaluvankulam & $\mathrm{S3}$ & 2.82 & 0.02 & 1.12 & 179 & 37 & 72 \\
\hline Chinthamani & $\mathrm{S} 4$ & 4.83 & 0.56 & 0.10 & 93 & 177 & 35 \\
\hline Samanatham & $\mathrm{S} 5$ & 2.75 & 1.30 & $\mathbf{2 . 9 0}$ & 241 & 55 & 50 \\
\hline Sottathatti & $\mathrm{S6}$ & 4.50 & 0.01 & $\mathbf{6 . 5 6}$ & 158 & 42 & 20 \\
\hline Virathanoor & $\mathrm{S} 7$ & 2.41 & 0.02 & 0.24 & 107 & 37 & 67 \\
\hline Mean & & 3.30 & 0.29 & 1.71 & 154.29 & 63.86 & 49.43 \\
\hline Median & & 2.82 & 0.02 & 1.02 & 158 & 45 & 50 \\
\hline SD & 1.24 & 0.49 & 2.36 & 54.04 & 50.42 & 20.04 \\
\hline Indian Standard (Awasthi, & & 1.5 & 1.5 & 2.5 & 50 & 30 & - \\
2000) & & & & & & \\
\hline WHO/FAO, 2007 & & - & 0.2 & 5.0 & 60 & 40 & -
\end{tabular}

Table 4. Effect of waste water irrigation on crop yield

\begin{tabular}{cccccc}
\hline Places & Sites & Cropped area (ha) & Types of Crops & $\begin{array}{c}\text { Seasons (Kharif, } \\
\text { Rabi) }\end{array}$ & $\begin{array}{c}\text { Paddy Mean } \\
\text { Yield (kg/ha) }\end{array}$ \\
\hline Thuvariman & S1 & 48 & Paddy, Banana, & \\
\hline Coconut & Both the seasons & $9500^{\mathrm{a}}$ & & & \\
\hline Avaniyapuram & $\mathrm{S} 2$ & 44 & $\begin{array}{c}\text { Paddy, Fodder } \\
\text { Grass }\end{array}$ & Both the seasons \\
\hline Kaluvankulam & $\mathrm{S} 3$ & Paddy & Rabi & $9000^{\mathrm{b}}$ \\
\hline Chinthamani & $\mathrm{S} 4$ & 72 & Paddy & Rabi & $8750^{\mathrm{C}}$ \\
\hline Samanatham & $\mathrm{S} 5$ & 32 & Paddy, Banana & Rabi & $9000^{\mathrm{b}}$ \\
\hline Sottathatti & $\mathrm{S} 6$ & 72 & Paddy & Rabi & $9000^{\mathrm{b}}$ \\
\hline Virathanoor & $\mathrm{S} 7$ & 48 & Paddy & Rabi & $8750^{\mathrm{C}}$ \\
\hline
\end{tabular}

Alphabets a to $c$ indicates the significant difference at $p<0.01$

\section{Results and discussion}

\subsection{Physico-chemical properties of soil}

The soil texture was found to be generally clay loam soil. The soil $\mathrm{pH}$ values ranged from 7.93-8.8. The control site S1 (Thuvariman, Bore water irrigation), have lower $\mathrm{pH}$ values than other wastewater irrigation sites (Table 1 ). The EC values ranges from $136-770 \mathrm{dS} / \mathrm{cm}$ and Organic Carbon $(\mathrm{OC}$ ) values lies $0.42-.82 \%$ in all sites, lower values noticed in bore water irrigation site (S1) than wastewater irrigation areas (S2, S3, S4, S5, S6 and S7). Long-term sewage irrigation may cause an increase in the $\mathrm{OM}$ content of irrigated soils. Similarly, EC values for sites S1, S3 (Kaluvankulam), and S7 (Virathanoor) are harmless to salinity effect and S2 (Avaniyapuram), S4 (Chinthamani), S5 (Samanatham) and S6 (Sottathatti) are have higher values causing salinity effect and limit yield for crops. The surface soil $(0-20 \mathrm{~cm})$ was richer in nutrients, availability of $\mathrm{N}, \mathrm{P}, \mathrm{K}$ in soils improved with sewage water irrigated sites, S6 have higher accumulated nutrients than other sites. The $\mathrm{N}, \mathrm{P}, \mathrm{K}$ values ranges from $112-434 \mathrm{~kg} / \mathrm{ha}$, $22-150 \mathrm{~kg} / \mathrm{ha}$ and $229-948 \mathrm{~kg} / \mathrm{ha}$ respectively. The $\mathrm{N}$ values are $<280 \mathrm{~kg} / \mathrm{ha}$ for low values for all sites than S6 (Sottathatti) compared with standard limit values, $P$ values $>22 \mathrm{~kg} / \mathrm{ha}$ for all sites compared with standards and $\mathrm{K}$ for all sites $>280 \mathrm{~kg} / \mathrm{ha}$ higher in values than translocation of metals from soil to other parts of the plants. 
$\mathrm{Pb}(2.29), \mathrm{Cd}(0.70)$. The present concentrations of metals were compared with permissible limits of Indian Standards (Awasthi, 2000) and also international safe limits. However, the heavy metal present in control site is lower limit than other sites.

\subsection{SEM analysis}

The soil samples were scanned at various magnification modes to collect general information about morphological characteristics. From Figure 2, it is observed that, site S1 (Thuvariman) soil sample image, appear rather rough and the particles are well aggregated and finer $(10 \mu \mathrm{m})$ grains are loosely aggregated on the surface. With respect to the site S2(Avaniyapuram) untreated wastewater irrigated soil, SEM image showed that the most of the material consists of grains greater than $10 \mu \mathrm{m}$ in diameter, coarse grains and are mostly of quartz (usually well-rounded), or more angular in shape. It also confirms that particles have porous and cracking structure. The site S3 (Kaluvankulam), irrigated with treated and untreated wastewater, the soil image from SEM analysis revealed that loose aggregate of fine grains and the surface of grains to be thickly coated in platy to poorly crystalline and the very bright grains with rough surfaces. The next site S4 (Chinthamani), using untreated wastewater for irrigation, SEM image showed that the soil samples are small, flaky or platy coatings on larger grains are probably clay. The loose aggregates of small grains are noticed in the surface. Many of the finer $(<10 \mu \mathrm{m})$ grains are loosely aggregated into larger particles. In the case of S5 (Samanatham) using untreated wastewater for agriculture purposes, the SEM image illustrated that the flocculated arrangement of loosely packed grains. Shapes of soil particles were found to be angular with non-uniformed shapes. The surfaces were rough with sharp corners. Distribution of grain size of soil was within a range of 10 to $200 \mu \mathrm{m}$ with clearly defined porosity. SEM image of the site S6 (Sottathatti), showed that the microstructure is more porous where pore spaces are relatively large. The surface of soil structure consists of thin plate like morphology. As shown in Figure 2, structure of soil consisted of many sheet-like particles. The flaky and plate-like particles could be identified as minerals. Soils that have flaky shape are likely to have high compressibility. The site S7 (Virathanoor), SEM image illustrated that, the soil structure aggregates is clearly visible in the image. Those aggregates having three-dimensional structure are very different in shape, size, stability and interior structure. The aggregate structure has a strong influence on soil strength. This SEM image analysis clearly interprets that waste water irrigation continuously disturbs the soil structure. It confirms the fact that plants growing in structurally degraded soils are often constrained by water-logging and poor aeration when the soil is wet and by high strength, rather than by the availability of water, as the soil dries. Excessive contamination of these heavy metals may also have an adverse effect on soil structure, causing a decline in soil permeability, and therefore in a soil's ability to further accept and treat wastewater. Hence these soil properties need to be considered before applying the quantity of waste water for irrigation.

\subsection{Heavy metal concentrations in paddy straw}

The heavy metal concentrations for paddy straw are presented in Table 3. The concentration ( $\mathrm{mg} / \mathrm{kg}$, dry wt.) of heavy metal in control site (S1) was found in the order of $\mathrm{Zn}(192)>\mathrm{Cu}(54)>\mathrm{Mn}(35)>\mathrm{Ni}(1.52)>\mathrm{Pb}(0.04)>\mathrm{Cd}(0.01)$, whereas other sites heavy metal mean concentrations level was found in the order of $\mathrm{Zn}(154.29)>\mathrm{Cu}(63.86)>$ $\mathrm{Mn}(49.43)>\mathrm{Ni}(3.30)>\mathrm{Pb}(1.71)>\mathrm{Cd}(0.29)$ respectively. The Cd mean values for both soil $(0.7 \mathrm{mg} / \mathrm{kg})$ and paddy straw $(0.29 \mathrm{mg} / \mathrm{kg})$ respectively, there is no significance difference were found for both soil and paddy straw.

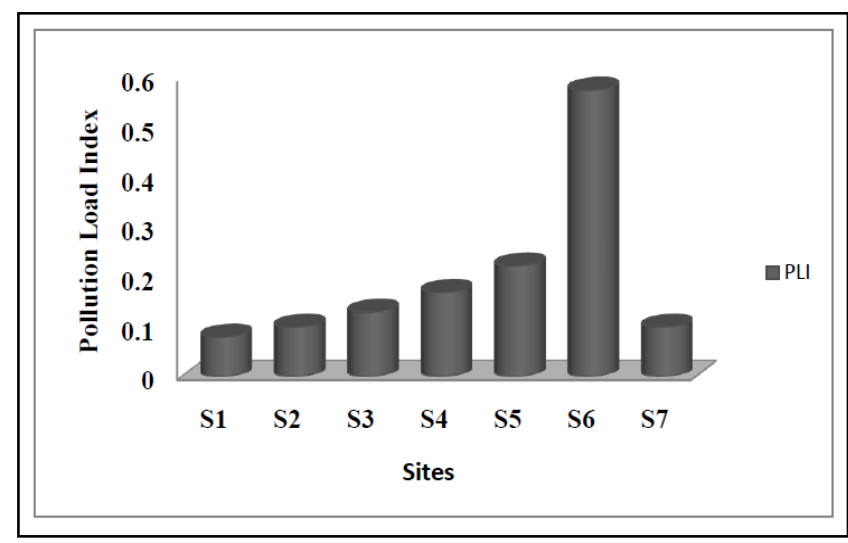

Figure 3. Pollution load index in the study area

Irrigation through untreated waste water increased the concentration of heavy metals in paddy plants. The concentrations of all the heavy metals showed spatial variations, which may be ascribed to the variations in heavy metal sources and the quantity of heavy metals discharged through the sewage and effluents in irrigation water. Absorption and accumulation of heavy metals in plant tissue depend upon many factors, which include temperature, moisture, organic matter, $\mathrm{pH}$, and nutrient availability. Soil properties influencing heavy metal availability varied significantly between the sites. In the case of $\mathrm{S} 5$ and $\mathrm{S6}, \mathrm{Pb}$ content was higher than the prescribed safe limits, similarly $\mathrm{Ni}$ also was higher than the safe limit in all the locations. In the case of $\mathrm{Cd}$ it is well within the Indian standards in all the locations. The consumption of $\mathrm{Ni}$ and $\mathrm{Pb}$ contaminated portion of paddy by people/live stock may pose serious health hazards in long run (Sharma et al., 2006, 2007). Interesting thing to observe is that the contamination levels were higher than permissible limits in the plant tissue, at the same sites where soil samples comply with established safe standards. Cd was easily absorbed by plants and transported to different parts of plants and no beneficial effects to plants (Jarvis, 1976). The $\mathrm{Zn}, \mathrm{Cu}$ and $\mathrm{Mn}$ concentrations values were higher in paddy straw than in soil. These metals are required for various activities and plays important roles in growth of the plant and photosynthesis (Tripathi et al., 1997). The heavy metals like $\mathrm{Ni}$ and $\mathrm{Pb}$ required continuous monitoring and suitable measures are needed before these poses serious problems. Crop growth parameters and yield attributes are also significantly influenced by the waste water irrigation (Data not shown). Average yield obtained for 
paddy from different sites are presented in Table 4. Data showed that the waste water irrigation significantly influenced the yield when compared to bore well irrigation water. Slight reduction in yield is due to the excess EC, Sodium content and alkaline $\mathrm{pH}$, which might have influenced the uptake of other nutrients. Even though the waste water may contain appreciable quantity of plant essential nutrients, organic carbon and the other factors such as $\mathrm{Na}$, TDS, heavy metals and EC needs to be taken care of, otherwise it will have a negative impact on the crop yield in the long run. Post harvest soil samples were analyzed for the impact of waste water irrigation. Salient results are discussed: Soil $\mathrm{pH}$ values vary from 7.1 to 9.4 in all these sites; EC values ranges from 0.2 to $2.1 \mathrm{dS} / \mathrm{m}$; Organic Carbon varied from 0 . To $1.8 \%$ and as expected continuous irrigation had a significant effect over soil properties when compared with the fresh water irrigated area.

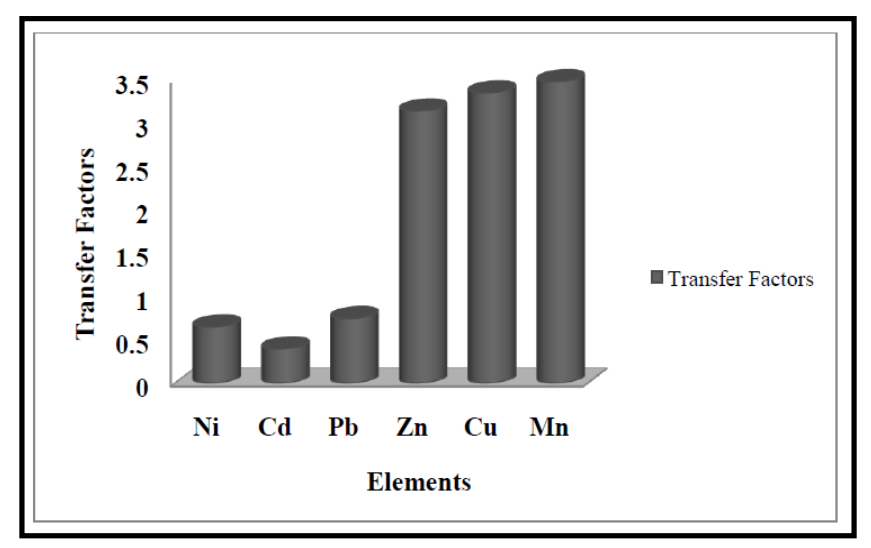

Figure 4. Transfer factors of heavy metals from soil to paddy straw

\subsection{Pollution load index}

The calculated PLI values varied from 0.08(S1)-0.56(S6) and are presented in Figure 3. The lowest values was identified at control site (S1, Bore water irrigation) and higher values are observed at S6 (Sottathati) site, whereas untreated wastewater is used for irrigation, other values are S2 (0.1), S3(0.13), S4(0.17), S5(0.223) and S7(0.1) respectively.

\subsection{Enrichment factor}

The enrichment factor (EF) in all sites for heavy metals were found in the descending order of $\mathrm{Pb}(53.2)>\mathrm{Cu}$ (10.64) >Cd (6.5) $\mathrm{Zn} \mathrm{(3.16)}>\mathrm{Ni}$ (3.16) >Mn (0.79) respectively and are presented in Table 5 . Significant difference in EF values were observed among all the heavy metals. The values of EF greater than 1 , indicates the chances of accumulation of metals in plant species where wastewater is used for irrigation (Kisku et al., 2000). Among six metals estimated, the maximum EF was found to be $\mathrm{Pb}$ for soil, $\mathrm{Ni}$ and $\mathrm{Zn}$ are moderate enrichment, $\mathrm{Cd}$ and $\mathrm{Cu}$ are significant enrichment, $\mathrm{Mn}$ is deficiency to mineral enrichment respectively.

\subsection{Translocation factor}

The ability of heavy metal species to transfer from the soil into plant roots is referred to as transfer factor (TF). The concentration of metals in this study area were within the normal standards. The TF of the heavy metals from soil to paddy straw in the study area are presented in Figure 4. The TF values are in order from $\mathrm{Zn}(31.5)>\mathrm{Mn}$ (3.49) $>\mathrm{Cu}$ (3.36) $>\mathrm{Ni}(0.653)>\mathrm{Pb}(0.75)>\mathrm{Cd}(0.40)$ respectively. The high toxic element concentrations indicate that some degree of heavy metal contamination occurred in the crops. According to study conducted by Sajjad et al. (2009), if the transfer factor coefficient of heavy metal is greater than 0.50 , the plant will have a greater chances of heavy metals contamination by anthropogenic activities. This indicates that the values of $\mathrm{Ni}, \mathrm{Pb}$ and $\mathrm{Cd}$ concentrations of heavy metals in the plant are low but, there is a chance for it to be contaminated with $\mathrm{Zn}, \mathrm{Cu}$ and $\mathrm{Mn}$ by further anthropogenic activities. In world populations, most affected heavy metal toxicity are pregnant women and children (Boon and Soltanpour, 1992), central nervous system destruction, body organs cancers and disorders of neurological are some of the common report for heavy metal poisoning (ASTDR, 2000), hence enough mitigation measures need to be adopted in these areas.

In nutshell, the issue is that the contamination levels were higher than permissible limits in the plant tissue for some heavy metals at the site where even soil samples showed the value of heavy metals within the prescribed limits. This study suggests that imperative consideration is required to focus on regular monitoring and pollution control mainly to ensure food for human consumption and regularize the use of sewage for irrigation. This indicates, enough caution should be given to farmers for the use of waste water for irrigation. This has important implications for policy and programmes which should be aimed at monitoring and controlling the level of heavy metal concentrations in irrigation water sources. Policies and programs need to be adapted so that local edaphic conditions and agricultural practices are taken into account, and appropriate local measures developed for ameliorating heavy metal uptake by crops for a given set of local conditions. These measures need to be regularly reviewed to take into account factors such as the accumulation of heavy metals in the topsoil over time.

Table 5. The enrichment factor for heavy metals in soil

\begin{tabular}{ccc}
\hline Metals & $\begin{array}{c}\text { Enrichment } \\
\text { Factors }\end{array}$ & \\
\hline $\mathrm{Ni}$ & 3.16 & Moderate Enrichment \\
\hline $\mathrm{Cd}$ & 6.5 & Significant Enrichment \\
\hline $\mathrm{Pb}$ & 53.2 & Extremely high Enrichment \\
\hline $\mathrm{Zn}$ & 3.61 & Moderate Enrichment \\
\hline $\mathrm{Cu}$ & 10.64 & Significant Enrichment \\
\hline $\mathrm{Mn}$ & 1.79 & Deficiency to mineral Enrichment \\
\hline
\end{tabular}

\section{Conclusions}

In the present study, soil and plant samples were collected from peri-urban region of Girudhumal sub basin area in Madurai district, Tamil Nadu, India irrigated with urban sewage wastewater. The results showed that the value of $\mathrm{pH}$ for both soil and paddy straw are within the permissible limits. EC values for S1 and S7 are within 
permissible limit than other sites; possess salinity affect to soil and in long run will affect soil quality (soil fertility \& structure) and limit the yield crops. The OC values are low in S1, medium in S2 site and high in other five sites, which may be due to use of long time wastewater irrigation. The nutrients values in all the sites showed that, $\mathrm{N}$ values are observed moderate in all sites, whereas $P$ and $K$ values are more than the permissible limit prescribed by Indian Standards. However, this accumulation of nutrients in the soil due to decades of untreated wastewater irrigation is a boon for agricultural production, since these nutrients are essential for plant growth, hence farmers can save money by reducing the quantity of $\mathrm{P}$ and $\mathrm{K}$ fertilizers. The micro nutrients $\mathrm{Fe}, \mathrm{Mn}, \mathrm{Zn}$ and $\mathrm{Cu}$ are also within standards limit. From the SEM images, it is observed that control site (bore water irrigation) shows clear morphological characteristics of soil, particles are well graded and other wastewater irrigation sites shows soil particles as flaky and plate-like particles which could be identified as minerals and the surface of grains to be thickly coated in platy to poorly crystalline. This structural deformation will result in poor growth of plants. The heavy metals $\mathrm{Ni}, \mathrm{Pb}$ and $\mathrm{Cd}$ were assessed for both soil and paddy straw to determine the status of pollution load in the soil. The Pollution Load Index (PLI) values indicated that all the values are within 1, and there is a less chance of metal pollution in the soil. The EF values for metals, Ni (3.16) and $\mathrm{Zn}$ (3.61) shows moderate enrichment, $\mathrm{Cd}$ (6.5) and $\mathrm{Cu}$ (10.64) shows significant enrichment, $\mathrm{Pb}$ (53.2) is extremely high and $M n$ (1.79) deficiency to mineral enrichment. The transfer factor of heavy metals from soil to paddy straw are less than 0.5 for $\mathrm{Cd}$, indicates less intake by the plant and that for other metals are greater than 0.5 suggesting the possibility of heavy metal contamination. Long time wastewater irrigation more than decades impacts on soil quality and in turn may reduce value of land and periodic monitoring of soil quality levels are needed for effective irrigation management.

\section{Acknowledgements}

Authors profoundly thankful to laboratory facilities provided by Thiagarajar college of Engineering, Madurai, and Soil and Environment department, Tamil Nadu Agricultural University, Madurai for completion of this work. SEM analysis facilities offered by The Director, School of Civil Engineering, Karunya University, Coimbatore, Tamil Nadu acknowledged.

\section{References}

Allen S.E., Grimshaw H.M. and Rowland A.P. (1986), Chemical Analysis, in: Moore P.D., Chapman S.B. (Eds.), Methods in Plant Ecology, Blackwell Scientific Publication, Oxford, London, pp. 285-344.

Assadian N.W., Fenn L.B., Flores-Ortiz M.A. and Ali A.S. (1999), Spatial Variability of solutes in a pecan orchard Surfaceirrigated with untreated effluents in the Upper Rio Grandle River Basin, Agricultural Water Management, 42(2), 143156.

ATSDR, Agency for Toxic Substances and diseases Registry (2000), Toxicological profile for Arsenic, Agency for Toxic
Substances and Disease Registry, US Department of Health and human services, Public Health Service. 205-1999-00024.

ATSDR, Agency Toxic Substances and Diseases registry (1999), Toxicological profile for Cadmium and Nickel, Agency for Toxic substances and disease Registry, US.

Awashthi S.K. (2000), Prevention of food Adulteration Act.no.37 of 1954, Central and State Rules as Amended for 1999, Ashoka Law House, New Delhi.

Barman S.C., Sahu R.K., Bhargava S.K. and Chatterjee C. (2000), Distribution of heavy metals in wheat, mustard and weed grains irrigated with industrial effluents, Bulletin of Environmental Contamination and Toxicology, 64, 489-496.

Boon D.Y. and Soltanpour P.N. (1992), Lead, Cadmium and Zinc Contamination of Aspen Garden Soils and vegetations, Journal of Environmental Quality, 21, 82-86.

Broos K., Beyens H. and Smolders E. (2005), Survival of rhozobia in soil in sensitive to elevated Zinc in the absence of the host plant, Soil Biology and Biochemistry, 37, 573-579.

Cao Z.H. and Hu Z.Y. (2004), Copper contamination in Paddy soil irrigated with wastewater, Chemosphere, 41(2), 3-6.

Corcoran E., Nellemann C., Baker E., Bos R., Osborn D. and Savelli H. (Eds.) (2010), Sick Water? The central role of wastewater management in sustainable development, $A$ Rapid Response Assessment, United Nations Environment Programme, UNHABITAT, GRID-Arendal.

Cui J., Zhu Y.G., Zhai R.H., Chen D.Y., Hung Y.Z. Qui Y. and Liong J.Z. (2004), Transfer of metals from near a smelter in Nanning, China Environmental International, 30, 785-791.

Drechel P., Scott C.A., Rachid L., Redwood M. and Bahri A. (Eds.) (2010), Waste Water Irrigation and Health. Earthscan, London, UK, p. 404.

FAO (1992), The State of Food and Agriculture, 1992, FAO Agriculture series, No.2, ISSN 0081-4539.

Gupta S., Nayek S., Saha R.N. and Satpati S. (2008), Assessment of Heavy metal accumulation in marcropyte, agricultural soil and crop plants adjacent to discharge zone of sponge iron factor, Environmental Geology, 55, 731-739.

Hanjra M.A., Blackwell J., Carr G., Zhang F. and Jackson T.M. (2012), Wastewater irrigation and environmental health: implications for water governance and public policy, International Journal of Hygienic Environmental Health, 5(3), 255-269. doi: 10.1016/j.ijheh.2011.10.003.

Harikumar P.S., Nasir V.P. and Mujeebu Rahma M.P. (2009), Distribution of Heavy Metals in the Core Sediments of tropical wetlands system. International Journal of Environmental Science and Technology, 6(20), 225-232.

Henze M., Harremoes P., Jansen J.I.c. and Arvin E. (2002), Wastewater Treatment-Biological and Chemical Process, Third Edition, Springer.

Hoeks E., Carranza-Torres C. and Corkum B. (2002), Hoek-Brown failure criterion-2002 edition, Proceedings of NARMS-Tac, 267-273.

Huang J., Yuan F., Zeng G., Li X., Gu Y. and Shi L. (2017), Influence of $\mathrm{pH}$ on heavy metal speciation and removal from wastewater using micellar-enhanced ultrafiltration, Chemosphere, 173, 199-206.

Jackson M.L. (1973), Soil Chemical Analysis. Prentice Hall of India (Pvt) Ltd., New Delhi.

Jarvis S.C., Jones L.P.H. and Hopper J.M. (1976), Cadmium Uptake from solutions by plants and its transport from roots to shoots, Plant and Soil, 44, 179-191. 
Jat G.S., Singh B., Tomar B.S., Singh J., Ram H. and Kumar M. (2016), Seed yield and quality as influenced by growing conditions in hybrid seed production of bitter gourd (Momordica charantia L.) cv. Pusa Hybrid-1, Journal of Applied and Natural Science, 8(4), 2111-2115.

Kalavrouziotis I.K. and Koukoulakis P.H. (2009), Distribution of elemental interactions in Brussels sprouts plants, under the treated municipal wastewater, Journal of Plant Interactions, 4(3), 219-231.

Kalavrouziotis I.K., Koukoulakis P.H. and Kostakioti E. (2012), Assessment of metal transfer factor under irrigation with treated municipal wastewater, Agricultural Water Management, 103, 114-119.

Khan S., Farooq R., Shahbaz S., Khan M.A. and Sadique M. (2009), Health Risk Assessment of heavy metals for population via consumption of vegetables, World Applied Science Journal, 6(12), 1602-1606.

Kisku G.C., Barman S.C. and Bhargava S.K. (2000), Contamination of soil and plants with potentially toxic elements irrigated with mixed industrial effluent and its impact on the environment, Water, Air, and soil pollution, 120, 127-137.

Levy S., Kafri M., Carmi M. and Barkai N.(2011), The competitive advantage of a dual-transporter system, Science, 334(6061), 1408-1412.

Mapanda F., Mangawayana E.N., Nyamangara J. and Giller K.E. (2005), The effect of long term irrigation using wastewater on heavy metal contents of soil under vegetables in Harare, Zimbabwe, Agriculture, Ecosystem and Environment, 107, 151-165.

Martin S. and Griswold W. (2009), Human Health Effects of Heavy Metals, Environmental Science and Technology Briefs for Citizens, Center for Hazardous Substance Research, 15, 16.

Minhas P.S. and Lal K. (2010), Urban wastewater for irrigation: contamination by heavy metals, in: Lal R. (Eds.), Encyclopedia of Soil Science, 2nd ed., Taylor \& Francis, New York, 1(1), 1-4.

Minhas P.S. and Samra J.S. (2004), Wastewater Use in Peri-urban Agriculture: Impacts and Oppurtunities, Technical Report, Central Soil Salinity Research Institute, Karnal, Haryana, India. DOI: 10.13140/RG.2.1.2982.0961.

Minhas P.S., Khajanchi-Lal R.K., Yadav S.K., Dubey R.K. and Chaturvedi (2015), Long term impact of waste water irrigation and nutrient rates: I. Performance, sustainability and produce quality of peri-urban cropping systems, Agricultural Water Management, 156, 100-109.

Murtaza G., Gafoor A., Qadir M., Owenes G., Aziz A., Zia M.H. and Saifullah (2010), Disposal and use of sewage on agricultural lands in Pakistan-A review, Pedosphere, 20 (1), 23-34.

Nan Z., Li J., Zhang and Cheng G. (2002), Cadmium and Zinc interaction and their transfer in soil-crop system under actual field condition, Science of the Total Environment, 285, 187-195.

Papaioannou D., Kalavrouziotis I.K., Koukoulakis P. and Papadopoulos F. (2015), A proposed method for the assessment of the interactive heavy metal accumulation in soils, Global NEST Journal, 17(4), 835-846.

Piper C.S. (1966), Soil and Plant Analysis. Inter Sciences Publication Inc., New York.

Qadir M., Ghafoor A. and Murtaza G. (2000), Cadmium concentration in vegetables grown in urban soil irrigated with untreated municipal sewage, Environment, Development and Sustainability, 2, 11-19.

Qadir M., Wichelns D., Raschid L.R., Minhas P.S., Drechsel P., Bahri A. and McCornick P. (2007), Agricultural use of marginal-quality water: opportunities and challenges, in: Molden D. (Eds.), Water for Food, Water for Life: A Comprehensive Assessment of Water Management in Agriculture. Earthscan, London, UK.

Qadir M., Wichelns D., Sally L.R., McCornick P.G., Drechsel P., Bahri A. and Minhas P.S. (2010), The challenges of wastewater irrigation in developing countries. Agricultural Water Management, 97, 561-568.

Rattan R.K., Datta S.P., Chhonkar P.K., Suribabu K. and Singh A.K. (2005), Long-term impact of irrigation with sewage effluents on heavy metal content in soils, crops and groundwater - a case study, Agricultural Ecosystem and Environment, 109, 310-322.

Sharma R.K., Agrawal M. and Agrawal S.B. (2014), Responses of Beta vulgaris exposed to cadmium and zinc through soil drenching, Journal of Environmental Biology, 35, 727-732.

Sharma R.K., Agrawal M. and Marshall F.M. (2006), Heavy metals contamination in vegetables grown in waste water irrigated areas of Varanasi, India, Bulletin of Environmental Contamination and Toxicology, 77, 311-318.

Sharma R.K., Agrawal M. and Marshall F.M. (2007), Heavy metals contamination of soil and vegetables in suburban areas of Varanasi, India, Ecotoxicology and Environmental Safety, 66, 258-266.

Shuval (1990), World Bank Publications on Wastewater Reuse for Irrigation, Summary of World Bank Technical Paper No. 51, Wastewater Irrigation in Developing Countries, Health Effects and Technical Solutions.

Singh R., Singh D.P., Kumar N., Bhargava S.K. and Barman S.C. (2010), Accumulation and translocation of heavy metals in soil and plants from fly ash contaminated area, Journal of Environmental Biology, 31, 421-430.

Stanford S. and English L.(1949), Use of flame photometer in rapid soil test K and Ca, Agronomy Journal, 41, 446-447.

Surendran U., Sandeep O. and Joseph E.J. (2016), The impacts of magnetic treatment of irrigation water on plant, water and soil characteristics, Agricultural Water Management, 178, 21-29.

Surendran U., Sushanth C.M., George Mammen and Joseph E.J. (2017), FAO-CROPWAT model-based estimation of crop water need and appraisal of water resources for sustainable water resource management: Pilot study for Kollam district humid tropical region of Kerala, India, Current Science, 112, 76-86.

Surendran U., Sushanth C.M., George Mammen and Joseph E.J.(2014), Modeling the impacts of increase in temperature on irrigation water requirements in Palakkad district - a case study in humid tropical Kerala, Journal of Water and Climate Change, 5(3), 471-487.

Tamilnson D.L., Wilson D.L., Harris J.G. and Jeffney D.W.(1980), Problems in the assessment of heavy metal levels in estuaries and the formation of a pollution Index, Holger Wissmeeresunters, 33, 566-572.

Tripathi R.M., Raghunath R. and Krishnamoorthy T.M. (1997), Dietary intake of heavy metals in Bombay City, India. Science of Total Environment, 208, 149-159. 
Turekian K.K. and Wedepohl K.H.(1961), Distribution of the elements in some major units of the Earth's Crust, Geological Society of America Bulletin, 72, 175-192.

Walkey A. and Black C.A.(1934), An estimation of methods for determining organic carbon and nitrogen in the soil, Journal of Agricultural Science, 25, 598-609.

Water Year (2007), District Groundwater Brochure, Madurai District, Government of India, ministry of water resources, Central Groundwater board, South Eastern Coastal Region, Chennai.

WHO (2006), Guidelines of the Safe Use of Wastewater, Excreta and Grey Water: Wastewater Use in Agriculture, vol. 2. World Health Organization, Geneva, Switzerland.

Yadav R.K., Goyal B., Sharma R.K., Dubey S.K. and Minhas P.S. (2002), Post irrigation impacts of domestic sewage effluents on composition of soils, crops and ground water-a case study, Environment International, 28, 481-486.

Yan X., Liu M., Zhong J., Guo J. and Wu W.(2018), How Human Activities Affect Heavy Metal Contamination of Soil and Sediment in a Long-Term Reclaimed Area of the Liaohe River Delta, North China, Sustainability, 10 (2), 338.

Yang J., Reichert P. and Abbaspour K.C.(2007), Bayesian Uncertainty Analysis in the Distributed Hydrologic Modeling: A Case Study in the Thur River Basin (Switzerland), Water Resources Research, 43, W10401. http://dx.doi.org/10.1029/ 2006WR005497. 